\begin{tabular}{|c|c|c|}
\hline BIODIK & $\begin{array}{c}\text { BIODIK: Jurnal IImiah Pendidikan Biologi } \\
\text { ISSN 2580-0922 (online), ISSN 2460-2612 (print) } \\
\text { Volume 6, Nomor 04, Tahun 2020, Hal. 423-433 } \\
\text { Available online at: } \\
\text { https://online-journal.unja.ac.id/biodik }\end{array}$ & BIODIK \\
\hline
\end{tabular}

Research Article

open 2 Access

\title{
Meningkatkan Keterampilan Mengajar Guru Melalui Pendampingan Penyusunan Perangkat Pembelajaran dan penilaian HOTS
}

\section{(Improve teacher teaching skills throughassistance in the preparation of learning tools and HOTS assessment)}

Eva Nurul Malahayati ${ }^{\star}$, Mar'atus Sholihah

Universitas Islam Balitar

Jl. Majapahit No.2- 4, Sananwetan, Kec. Sananwetan, Kota Blitar, Jawa Timur 66137-Indonesia

${ }^{*}$ Corresponding Author: malahayatieva488@gmail.com

\begin{tabular}{|c|c|}
\hline Informasi Artikel & ABSTRACT \\
\hline $\begin{array}{l}\text { Submit: } 13-07-2020 \\
\text { Diterima: } 12-11-2020 \\
\text { Dipublikasikan: } 17-12-2020\end{array}$ & $\begin{array}{l}\text { The revised } 2013 \text { curriculum changes require teachers to be able to compile and } \\
\text { carry out learning with an emphasis on four elements, 1) Strengthening character } \\
\text { education (PPK), 2) Literacy Movement, 3) 4C (Critical Thinking and Problem } \\
\text { Solving, Creative, Communicative, and Collaborative), and 4) HOTS (Higher-Order } \\
\text { Thinking Skills) Assessment. Assistance in the preparation of HOTS learning and } \\
\text { assessment tools for teachers aims to improve teacher skills in making learning tools } \\
\text { according to the } 2013 \text { revised curriculum and developing HOT assessment } \\
\text { instruments. The instruments used in this study were the interview sheets, } \\
\text { observation sheets, and evaluation sheets developed by Donald Kirkpatrick (1975) } \\
\text { and the documentation was analyzed using the stages of data collection, data } \\
\text { reduction, data presentation, and drawing conclusions (Miles and Huberman, 1984). } \\
\text { The method of implementing this activity is in-house training, mentoring, and } \\
\text { implementation of the revised } 2013 \text { curriculum learning tool and HOT assessment } \\
\text { instrument. Furthermore, the teacher will implement the learning tools that have been } \\
\text { arranged according to the class. During the implementation of the learning tools, the } \\
\text { team will accompany and make observations. The results of the observations will be } \\
\text { used as material for joint reflection. The conclusion of this study the teacher can } \\
\text { arrange HOTS learning and assessment tools according to the demands of the } 2013 \\
\text { revised curriculum. } \\
\text { Keywords: : Mentoring, learning tools, HOTS assessment }\end{array}$ \\
\hline Penerbit & ABSTRAK \\
\hline $\begin{array}{l}\text { Program Studi Pendidikan } \\
\text { Biologi, Fakultas Keguruan dan } \\
\text { Ilmu Pendidikan, Universitas } \\
\text { Jambi }\end{array}$ & $\begin{array}{l}\text { Perubahan kurikulum } 2013 \text { revisi menuntut guru untuk dapat menyusun dan } \\
\text { melaksanakan pembelajaran dengan menitik beratkan pada empat unsur, 1) } \\
\text { Penguatan pendidikan karakter (PPK), 2) Gerakan Literasi, 3) 4C (Critical Thinking } \\
\text { and Problem Solving, Creative, Communicative, Dan Collaborative), dan 4) Penilaian } \\
\text { HOTS (Higher-Order Thinking Skills). Pendampingan penyusunan perangkat } \\
\text { pembelajaran dan penilaian HOTS bagi guru bertujuan untuk meningkatkan } \\
\text { keterampilan guru dalam membuat perangkat pembelajaran yang sesuai kurikulum } \\
2013 \text { revisi dan menyusun instrumen penilaian HOT. Instrumen yang digunakan } \\
\text { dalam penelitian ini adalah lembar wawancara, lembar observasi, dan lembar } \\
\text { evalusi yang dikembangkan oleh Donald Kirkpatrick (1975) serta dokumentasi yang } \\
\text { dianalisis dengan tahapan pengumpulan data, reduksi data, penyajian data, dan } \\
\text { penarikan kesimpulan (Miles dan Huberman,1984). Metode pelaksanaan kegiatan ini } \\
\text { yaitu in house training, pendampingan, dan impelementasi perangkat pembelajaran } \\
\text { kurikumum } 2013 \text { revisi dan instrumen penilaian HOT. Selanjutnya guru akan } \\
\text { mengimplementasikan perangkat pembelajaran yang telah disusun sesuai kelasnya, } \\
\text { Selama pengimplementasian perangkat pembelajaran, tim akan mendampingi dan } \\
\text { melakukan observasi. Hasil observasi akan dijadikan bahan refleksi bersama. }\end{array}$ \\
\hline
\end{tabular}


Kesimpulan dari penelitian ini guru dapat menyusun perangkat pembelajaran dan penilain HOTS sesuai tuntutan kurikulum 2013 revisi.

Katakunci: Pendampingan, Perangkat pembelajaran, Penilaian HOTS

This BIODIK : Jurnal IImiah Pendidikan Biologi is licensed under a CC BY-NC-SA (Creative Commons Attribution-ShareAlike 4.0 International License)

\section{PENDAHULUAN}

Kurikulum merupakan seperangkat rencana yang menjadi acuan dalam mencapai tujuan dan sekaligus pedoman dalam mncapai tujuan pendidikan (Sulfemi, 2018). Kebijakan perubahan kurikulum merupakan langkah strategis yang dilakukan pemerintah sebagai bentuk usaha mempersiapkan generasi masa depan dan hasil evaluasi, kajian, kritik, dan prediksi serta tantangan yang dihadapi sehingga kurikulum adalah produk dari sebuah kebijakan yang bersifat dinamis, kontekstual, dan relatif (Machali, 2014). Perubahan kurikulum merupakan hal yang wajar dan seyogyanya dilakukan sesuai dengan tuntutan dan tantangan zaman.

Perubahan kurikulum 2013 menjadi kurikulum 2013 revisi memberikan warna baru pada proses implementasinya. Kurikulum 2013 revisi mengarah pada implementasi penguatan pendidikan karakter (PPK), gerakan literasi, pembelajaran abad 21 yang terdiri atas Critical Thinking and Problem Solving, Creative, Communicative, dan Collaborative (4C), dan penilaian HOTS (Higher-Order Thinking Skills) (Prayitno, 2019). Penilaian pada kurikulum 2013 revisi meliputi tiga ranah, yaitu penilaian sikap dan perilaku, pengetahuan, dan keterampilan. Penilaian yang dilakukan terdiri dari penilaian atas pembelajaran (assessment of learning), penilaian untuk pembelajaran (assessment for learning), dan penilaian sebagai pembelajaran (assessment as learning) dengan memperhatikan prinsip, instrument, dan mekanisme prosedur penilaian dalam kurikulum 2013 revisi.

Tantangan yang dihadapi oleh seorang guru dalam menghadapi kurikulum 2013 revisi adalah guru harus dapat mengubah mindset ke pendekatan saintifik (Yani, 2014). Pendekatan saintifik bertujuan mengaktifkan dan menumbuhkan krativitas peserta didik. Proses pembelajaran berbasis pendekatan saintifik meliputi lima tahap yaitu mengamati (observing), menanya (questioning), mengumpulkan informasi (explore) atau mencoba (experimenting), mengasosiasi (associating), dan mengkomunikasikan (communicating). Proses belajar dapat dilakukan dimana saja, tidak hanya terjadi di ruang kelas tetapi juga di lingkungan sekolah, alam, dan masyarakat. Guru bukan satu-satunya sumber belajar, dan pembelajaran dimensi sikap tidak diajarkan secara verbal, tetapi melalui contoh dan keeladanan. Bentuk penilaian yang dilakukan berbasis kompetensi yaitu pergeseran dari penilaian melalui tes-mengukurkompetensi pengetahuan berdasarkan hasil saja-menuju penilaian otentik yaitu mengukur semua kompetensi sikap, keterampilan, dan pengetahuan berdasarkan proses dan hasil (Machali, 2014). Oleh karena itu, penggunaan pendekatan saintifik dalam pembelajaran diyakini dapat membentuk kreativitas peserta didik.

\section{Malahayati \& Sholihah}


Proses belajar tidak hanya terjadi di ruang kelas saja, tetapi juga di lingkungan sekolah, alam, dan masyarakat. Posisi guru bukan satu-satunya sumber belajar, dan pembelajaran dimensi sikap tidak diajarkan secara verbal, tetapi melalui contoh dan teladan guru.KeempatStandar Penilaian.Penilaian yang dilakukan adalah berbasis kompetensi yaitu pergeseran dari penilaian melalui tes untuk mengukur kompetensi pengetahuan berdasarkan hasil saja menuju penilaian otentik yaitu mengukur semua kompetensi sikap, keterampilan, dan pengetahuan berdasarkan proses dan hasil.Memperkuat model penilaian PAP (Penilaian Acuan Patokan) yaitu pencapaian hasil belajar didasarkan pada posisi skor yang diperolehnya terhadap skor ideal (maksimal). Mendorong pemanfaatan portofolio yang dibuat siswa sebagai instrumen utama penilaian

Merubah sebuah kebiasaan dari seorang guru sebagai sumber pembelajaran menjadi seseorang yang berperan sebagai fasilitator dalam pembelajaran harus bisa memberikan pengalaman mengajar yang aktif, kreatif dengan menerapkan modelmodel pembelajaran abad 21 . Selain itu guru harus memahami penyusunan RPP, pelaksanaan pembelajaran, pendesainan instrumen penilaian, pelaksanaan penilaian serta pengolahan dan pelaporan hasil penilaian. Sa'bani (2017) menyatakan bahwa kualitas penyusunan perencanaan pembelajaran oleh guru menentukan keberhasilan sebuah pembelajaran termasuk dalam kegiatan evaluasi. Perencanaan dalam pembelajaran berkaitan erat dengan perangkat yang disusun dan digunakan oleh guru. Perangkat pembelajaran merupakan hal yang harus dipersiapkan oleh guru di dalam melaksanakan proses pembelajaran.

Kenyataan di lapangan yang dihadapi para guru, khususnya guru yang ada di SMKI Anharul Ulum Kademangan adalah kesulitan dalam memilih pengalaman belajar yang menarik bagi siswa dan sesuai tuntutan kurikulum 2013 revisi. Pemenuhan penyusunan perangkat pembelajaran Kurikulum 2013 revisi di sekolah perlu mendapatkan perhatian yang serius (Afandi \& Badarudin, 2011; Indriani, 2015; Priyono, Sulistyorini, Iskandar, \& Mushthafa, 2016). Hal ini disebabkan adanya peraturan baru yang sering berubah secara cepat sering kali membuat para guru belum siap mempersiapkan peserta didik menghadapi perubahan zaman yang akan datang. Hasil observasi di lapangan menunjukkan guru kurang mempersiapkan pengalaman belajar yang akan diberikan kepada siswa sehingga siswa sering mengantuk dan kurang antusias ketika pembelajaran berlangsung. Pembelajaran masih cenderung belum mengajak siswa aktif berpikir kritis dan analitis. Lebih lanjut, penilaian pembelajaran juga lebih dominan pada soal atau pertanyaan mengingat dan memahami dari materi yang telah disampaikan oleh guru. Berdasarkan hasil wawancara dengan kepala sekolah SMKI Anharul Ulum Kademangan mengungkapkan bahwa guru-guru kesulitan dalam menerapkan model-model pembelajaran yang sesuai dengan pembelajaran abad 21 ke dalam proses pembelajaran karena sebagian besar guru SMKI An-Harul Ulum Kademangan berlatar belakang non kependidikan. Selain itu, beberapa guru menyatakan masih merasa kesulitan dalam memilih model pembelajaran yang tepat dan efektif untuk diterapkan sesuai dengan karakteristik siswa dan tuntutan kurikulum. Para guru juga 
kesulitan dalam menyusun soal HOTS karena kurangnya pengetahuan dan pengalaman guru. Selama ini guru hanya langsung mengambil soal dari buku paket atau lembar kerja siswa yang sebagian besar soal hanya soal mengingat (C1) dan memahami (C2). Soal-sola demikian itu merupakan kategori soal LOTS (Lower order Thinking Skills) yang masih kurang mengajak siswa untuk berpikir kritis. Berdasarkan permasalahan di atas, maka diperlukan solusi untuk mengatasi kendala yang ada melalui pendampingan langsung terhadap penyusunan perangkat pembelajaran dan penilaian HOTS bagi guru SMKI Anharul Ulum Kademangan.

\section{METODE PENELITIAN}

Jenis penelitian yang dilakukan merupakan penelitian kualitatif. Instrumen yang digunakan untuk proses pengumpulan data antara lain (1) panduan wawancara untuk guru dan kepala sekolah, (2) lembar observasi, (3) angket evaluasi untuk guru menggunakan model evaluasi 4 level yang dikembangkan oleh Donald Kirkpatrick (1975) yang terdiri dari 4 level yaitu: reaction, learning, behavior and result, dan (3) dokumentasi. Metode yang digunakan terdiri atas:

1. In House Training

In house training dilakukan untuk memberikan pembekalan materi terkait penyusunan perangkat pembelajaran kurikulum 2013 revisi dan penyusunan penilaian HOTS kepada guru-guru di SMKI Anharul Ulum Kademangan Blitar. Kegiatan in house training ini dilakukan dengan metode ceramah dan tanya jawab selama dua hari.

2. Pendampingan

Kegiatan pendampingan dilaksanakan setelah kegiatan in house training selesai dilakukan. Kegiatan ini menggunakan metode proyek penyusunan perangkat pembelajaran berbasis pendekatan saintifik mengandung unsur pendidikan karakter (PPK), gerakan literasi, pembelajaran abad 21 dan HOTS; melakukan peer teaching dengan sesama guru yang serumpun; penyusunan penilaian HOTS; dan praktek microteachindalam penerapannya di kelas. Kegiatan pendampingan dilakukan selama dua bulan.

Data yang diperoleh berupa data kualitatif dianalisis dengan tahapan (Miles dan Huberman,1984) pengumpulan data, reduksi data, penyajian data, dan penarikan kesimpulan.

\section{HASIL DAN PEMBAHASAN}

\section{Kegiatan In House Training (IHT)}

IHT dilaksanakan di Hall Kampoeng Coklat pada tanggal 24-25 Juli 2019. Peserta IHT adalah semua guru SMKI Anharul Ulum Kademangan. Adapun susunan kegiatan sebagai berikut.

\section{Malahayati \& Sholihah}


Kegiatan IHT dihadiri oleh 100\% dari peserta yang direncanakan hadir. Pada saat pelaksanaan kegiatan terlihat antusiasme peserta selama mengikuti serangkaian acara kegiatan $\mathrm{IHT}$. Hal tersebut terlihat jelas ketika kegiatan tanya jawab, banyak pertanyaan yang dilontarkan oleh peserta. Hasil angket evaluasi peserta kegiatan $\mathrm{IHT}$, indikator reaction level sebesar $78 \%$ mengungkapkan materi IHT yang disampaikan relevan terhadap kebutuhan mereka akan kurikulum K13 revisi dan penyusunan soal HOTS sehingga memberikan kontribusi terhadap peningkatan pengetahuan guru-guru khususnya di SMKI Anharul Ulum Kademangan.

Hasil indikator learning level sebesar $85 \%$ menunjukkan adanya kegiatan IHT meningkatkan pemahaman guru-guru SMKI Anharul Ulum terhadap implementasi K13 revisi, aplikasi komponen pendidikan karakter, literasi, keterampilan abad 21 (critical thinking \& problem solving, creative, collaborative, dan communicative), pembelajaran HOTS (high order thinking skills), dan penilaian HOTS.

Lebih lanjut, kegiatan IHT telah memberikan stimulus positif terhadap guruguru untuk melaksanakan pembelajaran sesuai dengan pedoman dan tuntutan kurikulum K13 revisi serta memberikan stimulus untuk membuat soal dengan taraf HOTS yang ditunjukkan dari hasil pernyataan indikator behaviour level sebesar $81 \%$ dan hasil indikator result level sebesar $80 \%$ yang menyatakan bahwa kegiatan IHT dapat menambah wawasan guru terhadap kurikulum, proses pembelajaran, dan pengelolaan kelas sesuai harapan dan tujuan pendidikan nasional, serta menambah wawasan tentang langkah-langkah penyusunan HOTS. Dengan demikian dapat disimpulkan bahwa kegiatan IHT dapat meningkatkan pengetahuan guru terhadap implementasi dan tuntutan kurikulum K13 revisi serta meningkatkan pengetahuan guru terhadap penyusunan soal HOTS.

\section{Kegiatan Pendampingan}

Kegiatan pendampingan dilaksanakan secara bertahap dalam waktu dua bulan yaitu bulan Agustus-September 2019 sehingga dihasilkan sebuah perangkat pembelajaran lengkap sesuai dengan kurikulum 2013 revisi dan instrumen penilaian HOTS. Kegiatan dilaksanakan di SMKI Anharul Ulum Kademangan. Peserta pendampingan adalah semua guru yang mengampu mata pelajaran produktif. Kegiatan pendampingan dibagi menjadi tiga bagian yaitu pendampingan penyusunan perangkat pembelajaran, pendampingan penyusunan soal HOTS, dan praktik pembelajaran.

\section{a. Pendampingan Penyusunan Perangkat Pembelajaran}

Pada kegiatan pendampingan penyusunan perangkat pembelajaran guru-guru SMKI Anharul Ulum dihadiri 90\% peserta. Kegiatan ini diawali dengan pemaparan materi singkat dan meminta masing-masing guru mata pelajaran (mapel) produktif untuk mengumpulkan perangkat pembelajaran yang telah dibuat.

Hasil observasi awal menunjukkan bahwa sebesar $60 \%$ guru menyusun perangkat pembelajaran berdasarkan pengalaman masing-masing dan belum sesuai 
dengan pedoman kurikulum $\mathrm{K} 13$ revisi. Hal tersebut ditindaklanjuti dengan memberikan pendampingan secara intensif pada setiap guru mapel mulai dari menyusun indikator, tujuan pembelajaran, pengalokasian waktu, menentukan pendekatan pembelajaran, model dan strategi pembelajaran, menyusun kegiatan pembelajaran $4 \mathrm{C}$, dan instrumen evaluasi. Setelah kegiatan pendampingan selama dua pertemuan selanjutnya peserta diminta mengumpulkan perangkat pembelajaran baru yang telah dibuat. Hasil penilaian perangkat pembelajaran dapat dilihat pada Tabel 1.

Tabel 1 Hasil penilaian perangkat pembelajaran

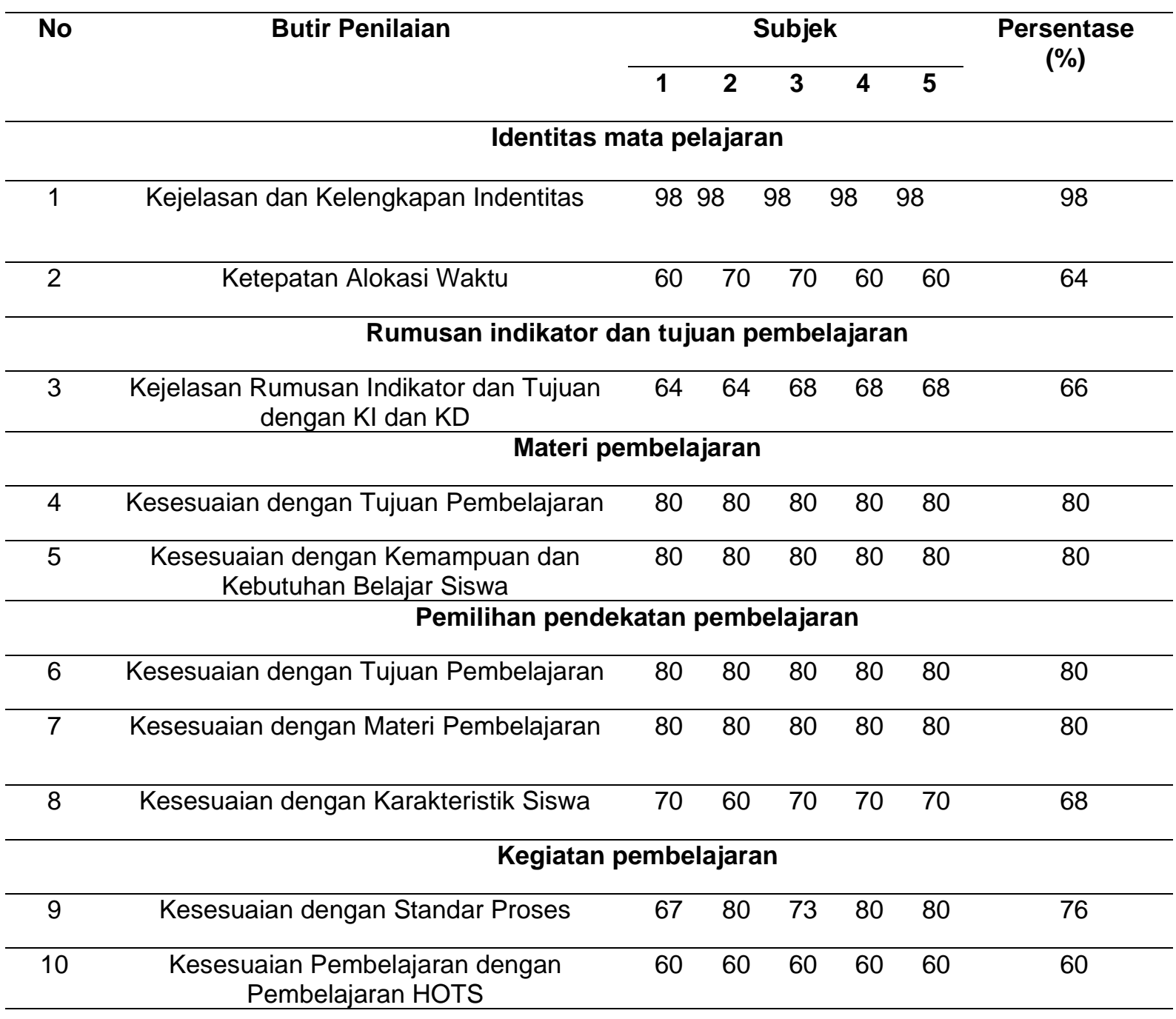

Pemilihan sumber belajar

\begin{tabular}{cccccccc}
\hline 11 & $\begin{array}{c}\text { Kesesuaian Sumber Belajar dengan Tujuan } \\
\text { Pembelajaran }\end{array}$ & 80 & 80 & 80 & 80 & 80 & 80 \\
\hline 12 & $\begin{array}{c}\text { Kesesuaian Sumber Belajar dengan Materi } \\
\text { Pembelajaran }\end{array}$ & 80 & 80 & 80 & 80 & 80 & 80 \\
\hline 13 & $\begin{array}{c}\text { Kesesuaian Sumber Belajar dengan } \\
\text { Karakteristik Siswa }\end{array}$ & 70 & 60 & 70 & 70 & 70 & 68 \\
\hline$\quad \begin{array}{c}\text { Penilaian hasil belajar } \\
14\end{array} \quad \begin{array}{c}\text { Kesesuaian Teknik Penilaian dengan Tujuan } \\
\text { Pembelajaran }\end{array}$ & 80 & 80 & 80 & 80 & 80 & 80 \\
\hline$\quad$
\end{tabular}




\begin{tabular}{ccccccccc}
\hline No & Butir Penilaian & \multicolumn{4}{c}{ Subjek } & & \multirow{2}{*}{$\begin{array}{c}\text { Persentase } \\
\text { (\%) }\end{array}$} \\
\cline { 3 - 5 } & & $\mathbf{1}$ & $\mathbf{2}$ & $\mathbf{3}$ & $\mathbf{4}$ & $\mathbf{5}$ & \\
\hline 15 & $\begin{array}{c}\text { Keberadaan dan Kejelasan Prosedur } \\
\text { Penilaian }\end{array}$ & 70 & 60 & 70 & 70 & 70 & 68 \\
\hline \multicolumn{1}{c}{ Total } & & & & & & 75 \\
\hline
\end{tabular}

Berdasarkan Tabel 1 perangkat pembelajaran yang dibuat oleh guru-guru di SMKI Anharul Ulum telah memiliki kejelasan identitas, rumusan indikator, tetapi tujuan pembelajaran belum dirumuskan sesuai kaidah penulisan ABCD. Deskripsi materi sesuai dengan kemampuan dan kebutuhan siswa, dimana guru telah menyajikan materi fakta, konsep, prinsip dan prosedur. Kesesuaian pendekatan pembelajaran dengan materi yang disampaikan dan karakteristik belajar siswa. kegiatan pembelajaran sudah sesuai dengan proses pembelajaran tetapi pembelajaran HOTS belum sepenuhnya diterapkan. Guru masih ragu-ragu dalam menerapkan pembelajaran HOTS dengan alasan waktu yang tersedia kurang. Pemilihan sumber belajar kurang bervariasi, masih terbatas pada lembar kerja siswa (LKS). Keberadaan dan kejelasan prosedur penilaian belum ada tetapi penilaian sesuai dengan tujuan pembelajaran hanya sampai tingkatan kognitif C3 (menerapkan).

\section{b. Pendampingan Penyusunan Penilaian HOTS}

Kegiatan pendampingan penyusunan penilaian HOTS dihadiri oleh $90 \%$ peserta dari guru-guru SMKI Anharul Ulum. Peserta tidak dapat hadir 100\% karena ada beberapa yang mendapatkan tugas untuk mendampingi kegiatan Agustusan siswa di sekolah. Kegiatan pendampingan diawali dengan pemaparan materi singkat tentang penyusunan soal HOTS kemudian meminta masing-masing peserta untuk mengumpulkan instrumen penilaian dalam hal ini adalah soal-soal yang telah dibuat oleh peserta. Berdasarkan telaah soal yang telah dikumpulkan para peserta, diketahui bahwa sebesar $80 \%$ soal yang dibuat oleh peserta belum berada pada kategori HOTS. Hanya dua soal yang berada pada kategori HOTS, sedangkan lainnya masih pada kategori LOTS yakni pada taraf mengingat, memahami, dan menerapkan. Dua soal yang sudah HOTS masih terbatas pada taraf menganalisis dan belum ada yang sampai pada taraf mengevaluasi dan mencipta. Hal tersebut ditindaklanjuti dengan memberikan pendampingan secara intensif pada setiap peserta mulai dari menyusun indikator soal, kisi-kisi soal, butir soal, dan rubrik jawaban. Setelah kegiatan pendampingan selama dua pertemuan selanjutnya peserta diminta mengumpulkan soal HOTS baru yang telah dibuat. Hasil telaah soal HOTS dapat dilihat pada Tabel 2. 
Tabel 2 Hasil telaah soal HOTS

\begin{tabular}{|c|c|c|c|c|c|c|c|}
\hline \multirow[t]{2}{*}{ No } & \multirow[t]{2}{*}{ Aspek yang ditelaah } & \multicolumn{5}{|c|}{ Subjek } & \multirow[t]{2}{*}{ Persentase (\%) } \\
\hline & & 1 & 2 & 3 & 4 & 5 & \\
\hline & \multicolumn{7}{|l|}{ Materi } \\
\hline 1. & Soal sesuai dengan KD materi & $\sqrt{ }$ & $\sqrt{ }$ & $\sqrt{ }$ & $\sqrt{ }$ & $\sqrt{ }$ & 100 \\
\hline 2. & $\begin{array}{l}\text { Soal menggunakan stimulus yang menarik (baru, } \\
\text { mendorong peserta didik untuk membaca) }\end{array}$ & $\sqrt{ }$ & $\sqrt{ }$ & $\sqrt{ }$ & $\sqrt{ }$ & $\sqrt{ }$ & 100 \\
\hline 3. & $\begin{array}{l}\text { Soal menggunakan stimulus kontekstual (gambar/grafik, } \\
\text { teks, visualisasi, dll, sesuai dengan dunia nyata) }\end{array}$ & $\sqrt{ }$ & $\sqrt{ }$ & $\sqrt{ }$ & $\mathrm{X}$ & $\mathrm{X}$ & 60 \\
\hline 4. & $\begin{array}{l}\text { Soal mengukur level kognitif penalaran (menganalisis, } \\
\text { mengevaluasi, mencipta) yang dalam penyelesaiannya } \\
\text { dicirikan dengan salah satu atau lebih tahapan proses } \\
\text { berpikir berikut: } \\
\text { - Transfer satu konsep ke konsep lainnya } \\
\text { - Memproses dan menerapkan informasi } \\
\text { - Mencari kaitan dari berbagai informasi yang berbeda- } \\
\text { beda } \\
\text { - Menggunakan informasi untuk menyelesaikan masalah } \\
\text { - Menelaah ide dan informasi secara kritis }\end{array}$ & $\sqrt{ }$ & $\sqrt{ }$ & $\sqrt{ }$ & $\mathrm{X}$ & $\sqrt{ }$ & 80 \\
\hline \multirow[t]{2}{*}{5.} & Jawaban tersirat pada stimulus & $\sqrt{ }$ & $\sqrt{ }$ & $\sqrt{ }$ & $\sqrt{ }$ & $\sqrt{ }$ & 100 \\
\hline & Konstruksi & & & & & & \\
\hline 6. & Memuat petunjuk yang jelas tentang cara mengerjakan soal & $\sqrt{ }$ & $\sqrt{ }$ & $\sqrt{ }$ & $\sqrt{ }$ & $\sqrt{ }$ & 100 \\
\hline 7. & $\begin{array}{l}\text { Ada pedoman penskoran/rubrik sesuai dengan } \\
\text { kriteria/kalimat yang mengandung kata kunci }\end{array}$ & $\sqrt{ }$ & $\sqrt{ }$ & $\sqrt{ }$ & $\sqrt{ }$ & $\sqrt{ }$ & 100 \\
\hline 8. & $\begin{array}{l}\text { Gambar, grafik, tabel, diagram, teks atau kalimat, dan } \\
\text { sejenisnya jelas dan berfungsi }\end{array}$ & $\sqrt{ }$ & $\sqrt{ }$ & $\sqrt{ }$ & $\sqrt{ }$ & $\sqrt{ }$ & 100 \\
\hline \multirow[t]{2}{*}{9.} & Butir soal tidak bergantung pada jawaban soal lain & $\sqrt{ }$ & $\sqrt{ }$ & $\sqrt{ }$ & $\sqrt{ }$ & $\sqrt{ }$ & 100 \\
\hline & Bahasa & & & & & & \\
\hline 10. & $\begin{array}{l}\text { Menggunakan bahasa yang sesuai dengan kaidah bahasa } \\
\text { Indonesia, untuk bahasa daerah dan bahasa asing sesuai } \\
\text { kaidahnya. }\end{array}$ & $\sqrt{ }$ & $\sqrt{ }$ & $\sqrt{ }$ & $\sqrt{ }$ & $\sqrt{ }$ & 100 \\
\hline 11. & Tidak menggunakan bahasa yang berlaku setempat/tabu & $\sqrt{ }$ & $\sqrt{ }$ & $\sqrt{ }$ & $\sqrt{ }$ & $\sqrt{ }$ & 100 \\
\hline 12. & Soal menggunakan kalimat yang komunikatif. & $\sqrt{ }$ & $\sqrt{ }$ & $\sqrt{ }$ & $\sqrt{ }$ & $\sqrt{ }$ & 100 \\
\hline \multicolumn{8}{|c|}{ Keterangan: } \\
\hline & $\begin{array}{l}=\text { sesuai dengan aspek } \\
=\text { tidak sesuai dengan aspek }\end{array}$ & & & & & & \\
\hline
\end{tabular}

Berdasarkan Tabel 2 soal yang dibuat oleh guru-guru di SMKI Anharul Ulum sebagian besar telah memenuhi kaidah pembuatan soal HOTS yaitu soal telah menggunakan stimulus yang menarik, baru, dan kontekstual, soal melibatkan beberapa tahapan proses berpikir dalam penyelesaiannya, dan jawaban tidak tersurat pada stimulus melainkan hanya tersirat. Meskipun sebagian besar soal yang dibuat oleh peserta sudah sesuai kaidah, tetapi masih ada dua peserta yang stimulusnya tidak kontekstual serta masih ada satu peserta yang belum melibatkan beberapa tahapan proses berpikir dalam penyelesaiannya. Hal ini dikarenakan para guru di SMKI Anharul Ulum terbiasa membuat soal dengan taraf mengingat dan memahami saja. Soal taraf mengingat dan memahami biasanya tidak memerlukan stimulus di awal soal dan tidak melibatkan beberapa tahapan proses berpikir untuk menjawab karena jawaban hanya bersifat hafalan. Membuat stimulus pada soal memang tidak mudah. Apalagi untuk orang yang belum terbiasa membuat soal 
dengan memberikan stimulus di awal soal. Agar dapat membuat stimulus soal yang menarik, baru, dan kontekstual serta mendorong peserta didik untuk membaca dan menganalisis, seorang guru harus memiliki pengetahuan dan wawasan yang luas. Stimulus yang kontekstual harus mengaitkan antara teori dengan fenomenafenomena dalam kehidupan sehari-hari.

Berdasarkan tata konstruksi dan bahasa, semua soal yang dibuat sudah menggunakan konstruksi dan bahasa yang baik dengan menyertakan petunjuk pengerjaan soal secara jelas, pedoman penskoran atau rubriknya jelas, stimulus pada soal berfungsi dengan jelas, jawaban tidak bergantung dengan jawaban soal lain, dan soal juga telah menggunakan bahasa yang komunikatif.

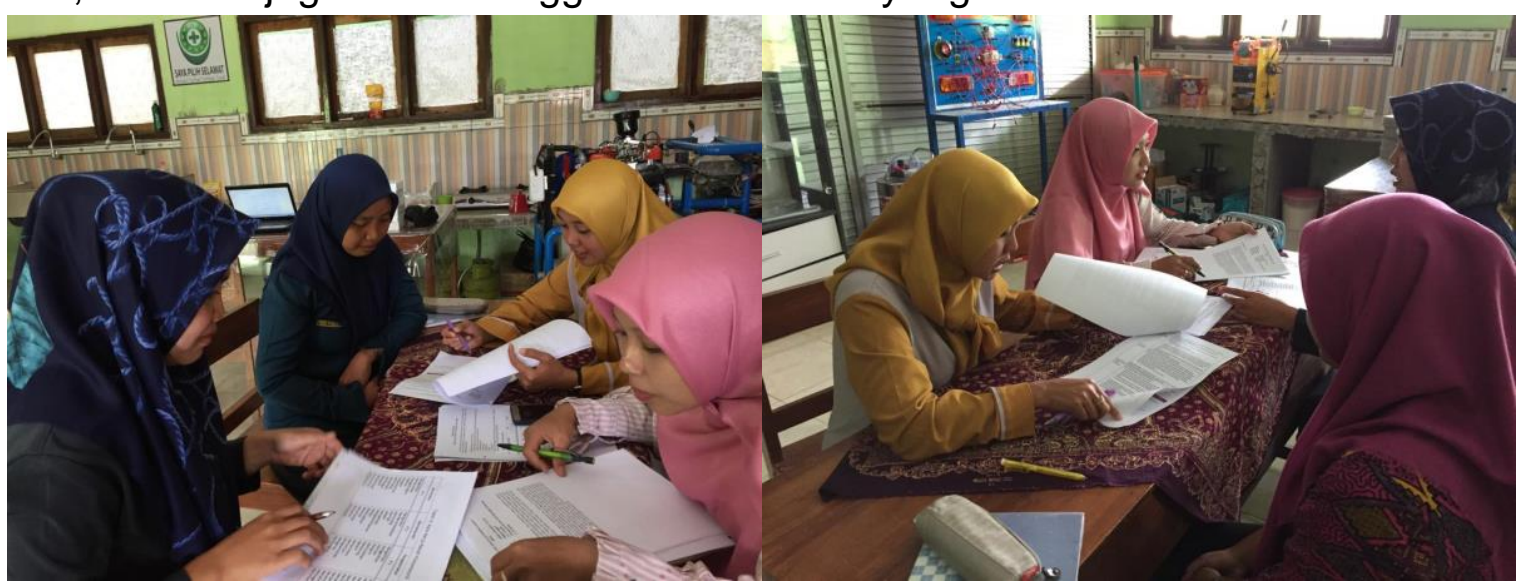

Gambar 1 Pendampingan peserta dalam menyusun perangkat pembelajaran dan penilaian HOTS

\section{c. Praktik Pembelajaran}

Kegiatan praktik pembelajaran diwakili oleh dua orang peserta yaitu guru mata pelajaran farmasi dan guru mata pelajaran agribisnis pengolahan hasil pertanian (APHP). Praktik pembelajaran dilaksanakan sesuai dengan jadwal pembelajaran yang ada di sekolah. Dari dua peserta yang melaksanakan praktik pembelajaran, keduanya telah melaksanakan pembelajaran sesuai kurikulum 2013 revisi dan memberdayakan siswa untuk berpikir tingkat tinggi (HOTS) dengan menyajikan kasus-kasus atau fenomena yang kontekstual dalam pembelajaran serta mengajak siswa untuk berpikir secara analisis. Tetapi praktik yang dilakukan oleh guru mata pelajaran farmasi tidak menyediakan lembar kerja siswa secara tertulis melainkan menyajikan kasus-kasus secara lisan untuk didiskusikan oleh siswa. Hal ini terjadi karena miskomunikasi antara guru yang praktik dengan instruksi kepala sekolah. Guru yang praktik menyiapkan perangkat pembelajaran untuk materi yang telah lewat atau yang telah diajarkan, padahal kegiatan praktiknya dilaksanakan sesuai dengan jadwal pembelajaran yang akan datang. Meskipun dalam penyiapan administrasi masih kurang, tetapi dalam pelaksanaannya guru mata pelajaran farmasi sudah memberdayakan peserta didik untuk dapat berpikir kritis dengan menganalisis fenomena-fenomena yang disajikan oleh guru secara lisan.

Praktik mengajar kedua dilakukan oleh guru mata pelajaran APHP. Kegiatan pembelajaran yang dilakukan guru mata pelajaran APHP juga sudah sesuai dengan 
kurikulum 2013 revisi dengan mengintegrasikan komponen 4C (critical thinking and problem solving, creative, collaborative, dan communicative) di dalam pembelajaran serta memberdayakan peserta didik untuk berpikir tingkat tinggi. Selain itu pembelajarannya juga menekankan pada pendidikan karakter untuk bertanggung jawab, disiplin, dan saling bekerjasama. Peserta didik disediakan lembar kerja yang memandu mereka untuk bekerja secara kelompok, memecahkan permasalahan bersama, dan memunculkan ide kreatif untuk memecahkan permasalahan. Dalam praktiknya guru APHP memandu peserta didik untuk melaksanakan kegiatan praktikum pengolahan hasil pertanian. Guru menginformasikan bahan utama yang harus diolah, kemudian peserta didik diminta mengajukan ide untuk cara dan variasi pengolahannya. Pertanyaan-pertanyaan diskusi yang ada pada lembar kerja siswa juga sudah mengarahkan siswa untuk bisa berpikir kritis dan kreatif. Secara keseluruhan pembelajaran yang dilaksanakan oleh guru praktik telah mencerminkan pembelajaran abad 21 dan sesuai tuntutan kurikulum 2013 revisi.

\section{KESIMPULAN}

Dari kegiatan pendampingan pembuatan perangkat pembelajaran dan penilaian HOTS ini dapat disimpulkan bahwa: (1) Kegiatan IHT dan pendampingan. Secara umum kegiatan berjalan dengan lancar. Guru mengikuti pelatihan dengan antusias, bertujuan untuk meningkatkan kompetensi dan keterampilan guru terkait dengan menyusun perangkat pembelajaran dan penilaian HOTS. (2) Produk perangkat pembelajaran dan penilaian HOTS. Dari kegiatan pendampingan ini, guru telah terampil mempraktikkan pembelajaran sesuai tuntutan kurikulum 2013 revisi. Perangkat pembelajaran dan penilaian HOTS telah mencerminkan tuntutan kurikulum 2013 revisi. Meskipun demikian, ada beberapa hal yang perlu ditingkatkan, misalnya dalam pemilihan sumber belajar kurang bervariasi, keberadaan dan kejelasan prosedur penilaian belum ada. Tentu saja hal ini memerlukan waktu dan latihan yang lebih lama lagi. Saran untuk penelitian selanjutnya terkait dengan: (1) Pendampingan dapat dilakukan secara lebih intensif untuk memfalisitasi guru dalam menyusun perangkat pembelajaran HOTS sesuai dengan Kurikulum 2013 revisi. (2) Untuk memperkaya wawasan guru mengenai ragam sumber belajar dan media pembelajaran, diperlukan waktu tersendiri untuk memberikan pelatihan bagi guru dalam membuat atau merancang sumber belajar dan media pembelajaran yang menarik bagi siswa.

\section{UCAPAN TERIMAKASIH}

Terimakasih banyak untuk Yayasan Pesantren KH. Dawami Nurhadi (YPKHD) Kademangan yang telah bersedia melakukan kerjasama. Kepala Sekolah dan Guru SMKI Anharul Ulum yang telah mengizinkan dan menyiapkan tempat pelaksanaan pelatihan serta berperan aktif dalam kegiatan pendampingan ini sehingga kegiatan ini dapat berjalan dengan lancar. 


\section{DAFTAR PUSTAKA}

Afandi, M., \& Badarudin, B. (2011). Perencanaan Pembelajaran di Sekolah: Dengan Memasukkan Pendidikan Budaya dan Karakter Bangsa. Bandung: Penerbit Alfabeta.

Hamalik, Oemar. (2004). Kurikulum dan Pembelajaran. Jakarta: Bumi Aksara.

Indriani, F. (2015). Kompetensi Pedagogik Mahasiswa Dalam Mengelola Pembelajaran Tematik Integratif Kurikulum 2013 Pada. Junal Profesi Pendidikan Dasar, 2(2), 87-94.

Machali, Imam. (2014). Kebijakan Perubahan Kurikulum 2013 dalam Menyongsong Indonesia Emas Tahun 2045. Jurnal Pendidikan Islam, 3, (1).

Prayitno, Wendhie. 2019. Bahan Ajar Pengenalan Pembelajaran Dan Penilaian Kurikulum 2013 (Terintegrasi PPK, Literasi, HOTS, 4Cs). Jakarta: Direktur Jenderal Guru dan Tenaga Kependidikan

Priyono, S., Sulistyorini, S., Iskandar, D., \& Mushthafa, M. (2016). Modul Kepala Sekolah Pembelajar Kelompok Kompetensi 06: Pengelolaan Kurikulum. (H. Hasan, H. Widyaistono, M. Mariati, \& M. Y. Saad, Eds.). Jakarta: Direktorat Jenderal Guru dan Tenaga Kependidikan.

Sa'bani F. (2017). Peningkatan Kompetensi Guru dalam Menyusun RPP melalui Kegiatan Pelatihan pada MTs Muhammadiyah Wonosari. Jurnal Pendidikan Madrasah, 1, (2).

Sulfemi, Wahyu Bagja. (2018). Manajemen Kurikulum Di Sekolah. Bogor : Visi Nusantara Maju.

Suryo Widodo, Variabel-Variabel Tersembunyi Dalam Guru Matematika Kreatif, Prosiding Seminar Nasional Matematika dan Pendidikan Matematika FMIPA UNY Yogyakarta, 9 November 2013 (Yogyakarta: FMIPA UNY, 2013), hlm. 587. Yani, Ahmad. (2014). Mindset Kurikulum 2013. Jakarta: Rineka Cipta. 